\title{
Rancang Bangun Sistem Informasi Absensi Karyawan Pada PT. San Andreas Mandiri Bekasi
}

\author{
Nova Rio ${ }^{1}$, Dicky Hariyanto², Elvi Sunita ${ }^{3}$ \\ 1,2,3 Universitas Bina Sarana Informatika \\ ${ }^{1}$ Nova.rio@gmail.com, ${ }^{2}$ dicky.dkh@bsi.ac.id, ${ }^{3}$ elvi.evt@bsi.ac.id
}

\begin{abstract}
In the current era of globalization, information technology is advancing rapidly. As a computer which is an equipment that was created to make it easier for humans, when achieving progress both in the manufacture of hardware and software. PT. San Andreas Mandiri provides every information system that supports and provides benefits in building a company. To ask the author to try to make a Final Project about the employee attendance system at PT. San Andreas Mandiri bekasi that has not been computerized. At this time PT. San Andreas Mandiri only consists of companies engaged in contracting, engineering, fabrication. Attendance system at PT. San Andreas Mandiri is still done manually, starting from making entry to making reports for absences, making it possible when the process occurs in recording, lack of accurate reports made and delays in processing the data needed. The design of this information system is the best solution for solving problems that exist in this company, and with a computerized system that can facilitate an activity that is effective and efficient in supporting the activities of this company. A computerized system is better than a manual system so that it runs more effectively and efficiently and the current employee attendance system is more conducive than the earlier system.
\end{abstract}

Keywords: Information System Designing, Employee Attendance System

Abstrak: Dalam era globalisasi sekarang ini,teknologi informasi melaju dengan cepatnya. Adapun komputer yang merupakan peralatan yang diciptakan untuk mempermudah pekerjaan manusia,saat mencapai kemajuan baikdi dalam pembuatan hardware maupun software.PT. San Andreas Mandiri membutukansekali adanya suatu sistem informasi yang menunjang dan memberikan manfaat dalam membangun perusahaan.Untuk itulah peneliti membuat sebuah sistem absensi karyawan pada PT. San Andreas Mandiri bekasi yang belum terkomputerisasi. Pada saat ini PT. San Andreas Mandiri hanya berupa perusahaan yang bergerak dalam bidang kontraktor, engineering, fabrikasi . Sistem absensi yang ada pada PT. San Andreas Mandiri ini masih dilakukan secara manual,mulai dari absen masuk hingga pembuatan laporan untuk absen, sehingga memungkinkan pada saat proses berlangsung terjadi kesalahan dalam pencatatan,kurang akuratnya laporan yang dibuat dan keterlambatan dalam pengolahan data-data yang diperlukan. Metodelogi yang dipilih pada penelitian ini menggunakan metode pengembangan perangkat lunak Waterfall serta dibantu dengan teknik pengumpulan data melalui wawancara, observasi dan studi pustaka. Tujuan pada penelitian ini diharapkan PT. San Andreas Mandiri dapat meminimalisir tingkat kesalahan pengambilan keputusan yang berkaitan dengan sistem absensi karyawannya.

Kata Kunci: Perancangan Sistem Informasi, Sistem Absensi Karyawan

\section{A. PENDAHULUAN}

Sistem informasi dan teknologi komputer berkembang sangat pesat sejalan dengan besarnya kebutuhan terhadap informasi. Perkembangan teknologi informasi tidak lepas dari pesatnya perkembangan teknologi komputer, karena komputer merupakan media yang dapat memberikan kemudahan bagi manusia dalam menyelesaikan suatu pekerjaan.Perubahan dan dinamika 
masyarakat yang semakin cepat seiring dengan perkembangan jaman dan teknologi sehingga memerlukan kualitas informasi yang akurat, cepat dan tepat. Teknologi informasi adalah salah satu contoh produk teknologi yang berkembang pesat dan dapat membantu manusia dalam mengolah data serta menyajikan sebuah informasi yang berkualitas. Dalam menyediakan informasi tersebut, diperlukan suatu alat bantu atau media untuk mengolah beraneka ragam data agar dapat disajikan menjadi sebuah informasi yang bermanfaat dengan kemasan yang menarik dan berpedoman pada criteria informasi yang berkualitas.

Setiap instansi perusahaan pemerintah maupun swasta pasti membutuhkan suatu sistem informasi didalam menjalankan aktifitas kerjanya sehingga lebih teratur dan terarah dengan lebih efisien. PT. San Andreas Mandiri merupakan salah satu perusahaan yang memakai sistem informasi berupa pemakaian perangkat komputer dalam menjalankan aktifitas kerjanya, tetapi penggunaanya belum secara menyeluruh, hanya memanfaatkan untuk hal-hal kecil saja, seperti dalam pembuatan surat-surat dan laporan-laporan serta dalam pengolahan data yang masih manual menggunakan buku-buku untuk mendatanya. Permasalahan lain yang kemudian timbul adalah terjadinya penumpukan berkas-berkas dilemari penyimpanan yang menyebabkan berkas tersebut rusak, serta lamannya waktu yang dibutuhkan untuk mencari data karena banyaknya berkas yang disimpan dilemari penyimpanan

\section{B. TINJAUAN PUSTAKA}

Menurut (Batubara, 2018) "Pembelajaran berbasis Web adalah pembelajaran yang pelaksanaanya didukung oleh bantuan teknologi internet, pembelajaran melalui web memerlukan sebuah model instruktur yang dirancang khusus untuk pengelolaan kegiatan pembelajaran tersebut $"$.

Menurut (Muslihudin \& Oktafianto, 2016)"Sistem adalah sebuah istilah yang secara kolektif mendeskripsikan fase-fase awal pengembangan sistem. Analisis sistem adalah teknik pemecahan masalah yang menguraikan bagian-bagian komponen tersebut bekerja dan berinteraksi untuk mencapai tujuan mereka".

Menurut (Batubara, 2018)"Web atau website adalah kumpulan dari halaman situs dan dokumen yang tersebar di beberapa komputer server yang berbeda di seluruh penjuru dunia dan terhubung menjadi satu jaringan melalui jaringan yang disebut internet".

Menurut (Kusrini, 2014)"Basis data adalah kumpulan data yang saling berelasi. Data sendiri merupakan fakta mengenai obyek, orang, dan lain-lain .Data dinyatakan dengan nilai (angka deretan karakter atau simbol) ".

Menurut (Rusmawan, 2019)“ Dalam membangun dan mengembangkan aplikasi ini perlu menggunakan metode waterfall. Waterfall merupakan salah satu metode pengembangan sistem informasi yang bersifat sistematis dan sekuensial,artinya setiap tahapan dalam metode ini dilakukan secaran berurutan dan berkelanjutan".

Menurut (Indrajani, 2015)"Entity Relationship Diagram adalah sebuah pendekatan top-bottom dalam perancangan basis data yang dimulai dengan mengidentigikasikan data-data terpenting yang disebut dengan entitas dan hubungan antara entitas-entitas tersebut di gambarkan dalam suatu model".

Menurut (Muslim, 2017)“UML adalah salah satu tool permodelan sistem berorientasi objek yang di gunakan untuk memperlihatkan banyak pandangan terhadap suatu sistem yang akan di bangun"

\section{METODE PENELITIAN}

Metode penelitian dan teknik pengumpulan data yang digunakan untuk penyusunan Tugas Akhir adalah sebagai berikut:

1. Metode Pengembangan Perangkat Lunak

Metode yang digunakan pada pengembangan perangkat lunak ini menggunakan model waterfall yang terbagi menjadi tiga tahapan yaitu:

a. Analisa Kebutuhan 
Analisa kebutuhan merupakan sebuah proses untuk mendapatkan informasi , model, spesifikasi tentang sesuatu yang diinginkan pengguna. Pada proses ini dilakukan penganalisaan serta pengumpulan data-data dan informasi untuk mendukung kebutuhan penulis. Penganalisaan dan pengumpulan data tersebut berupa sumber informasi dan perangkat lunak. Hasil data tersebut akan digunakan untuk melengkapi penyusunan perancangan sistem absensi karyawan.

b. Perancangan sistem dan perangkat lunak

Dalam perancngan ini, penulis mengugunakan metode rancangan model yang berorientasi objek dengan menggunakan UML (Unified Modeling Language) yaitu Use Case Diagram dan Activity Diagram.

c. Implementasi dan Pengujian Unit

Implementasi merupakan tahap melakukan penerapan sistem sehingga siap untuk dioperasikan. Implementasi bertujuan untuk mengkonfirmasi modul-modul perancangan, sehingga dapat memberikan hasil dalam pengoprasiaanya.

2. Teknik Pengumpulan Data

a. Obervasi

Teknik pengumpulan data dimana penulis melakukan pengamatan langsung ke bagian administrasi absensi karyawan dimana penulis mempelajari dan mengamati langsung proses absensi karyawan yang biasa dilakukan untuk mengetahui proses absensi karyawan tersebut.

b. Wawancara

Penulis melakukan wawancara langsung kepada beberapa admin di bagian absensi karyawan mengenai proses absensi karyawan pada untuk memperoleh data dan informasi yang penulis perlukan.

c. Studi Pustaka

Penulis juga melakukan studi pustaka dengan buku-buku yang berada dalam perpustakaan kampus maupun diluar kampus untuk melengkapi kekurangankekurangan bahan laporan yang berkaitan dengan sistem informasi yang dapat melengkapi data-data untuk membantu penulis dalam melengkapi laporan.

\section{HASIL DAN PEMBAHASAN}

1. Analisis Kebutuhan

Suatu Prosedur atau tahap-tahap yang dilakukan sebelum memulai suatu kegiatan untuk menyelesaikan suatu pekerjaan disebut prosedur sistem. Sesuai dengan ruang lingkup yang dibahas dalam penelitian ini maka analisis kebutuhan yang digunakan adalah sebagai berikut:

a. Kebutuhan Pengguna

Dalam perancangan absensi karyawan berbasis web PT. San Andreas Mandiri terdapat dua pengguna yang dapat saling berinteraksi dalam lingkungan sistem, yaitu admin dan karyawan. Kedua pengguna tersebut memiliki karakteristik interaksi dengan sistem yang berbeda-beda dan memiliki kebutuhan informasi yang berbeda-beda, seperti berikut :

1) Skenario kebutuhan bagian admin

a. Menerima data absensi

b. Mengecek data absensi

c. Membuat laporan absensi

d. Mengedit jabatan

e. Mengedit karyawan

2) Skenario kebutuhan bagian karyawan

a. Karyawan login untuk mengisi data absensi

b. Mengisi absensi masuk

c. Mengisi absensi pulang 
IJSE - Indonesian Journal on Software Engineering, Vol.5, No. 2, Desember 2019, 34-41 pISSN: 2461-0690 I eISSN: 2714-9935

b. Kebutuhan Sistem

1) Karyawan atau pengguna harus melakukan login terlebih dahulu untuk mendapatkan akses web ini dengan memasukan nomor induk pegawai

2) Saat ingin absen masuk karyawan atau pengguna melakukan absen masuk dengan memasukan nomor induk pegawai (NIP).

3) Saat ingin absen pulang karyawan atau pengguna melakukan absen pulang dengan memasukan nomor induk pegawai (NIP).

2. Use Case Sistem Yang Diusulkan

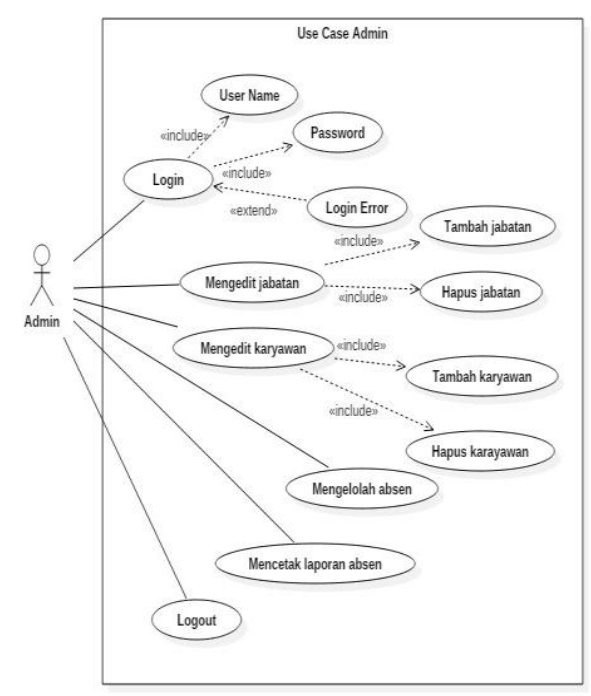

Sumber: Hasil Penelitian (2019)

Gambar 1. Diagram Use Case Admin Sistem Yang Diusulkan

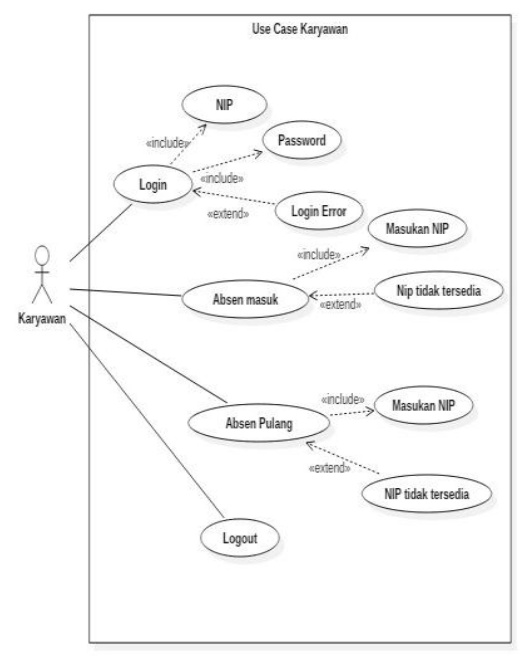

Sumber: Hasil Penelitian (2019)

Gambar 2. Diagram Use Case Karyawan Sistem Yang Diusulkan

ejournal.bsi.ac.id/ejurnal/index.php/ijse Copyright @ Universitas Bina Sarana Informatika 
3. Entity Relationship Diagram (ERD)

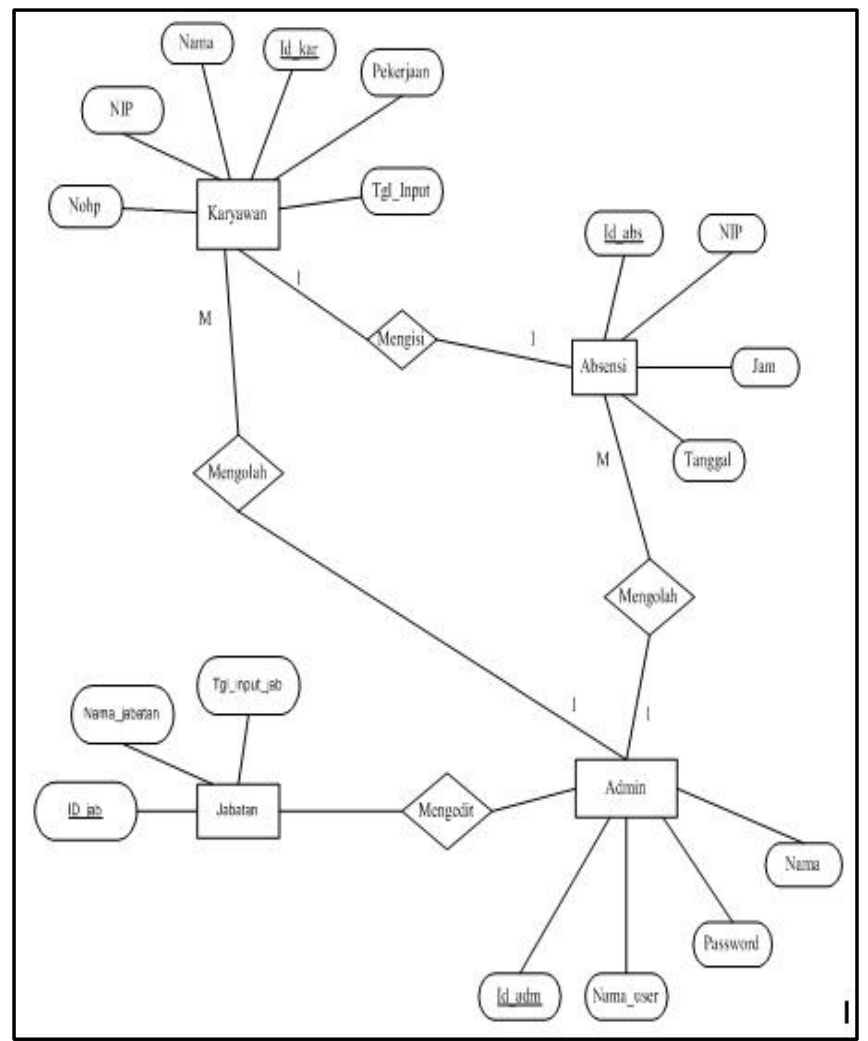

Sumber: Hasil Penelitian (2019

Gambar 3. ERD Sistem Yang Diusulkan 
IJSE - Indonesian Journal on Software Engineering, Vol.5, No. 2, Desember 2019, 34-41 pISSN: 2461-0690 I eISSN: 2714-9935

4. Logical Record Structure (LRS)

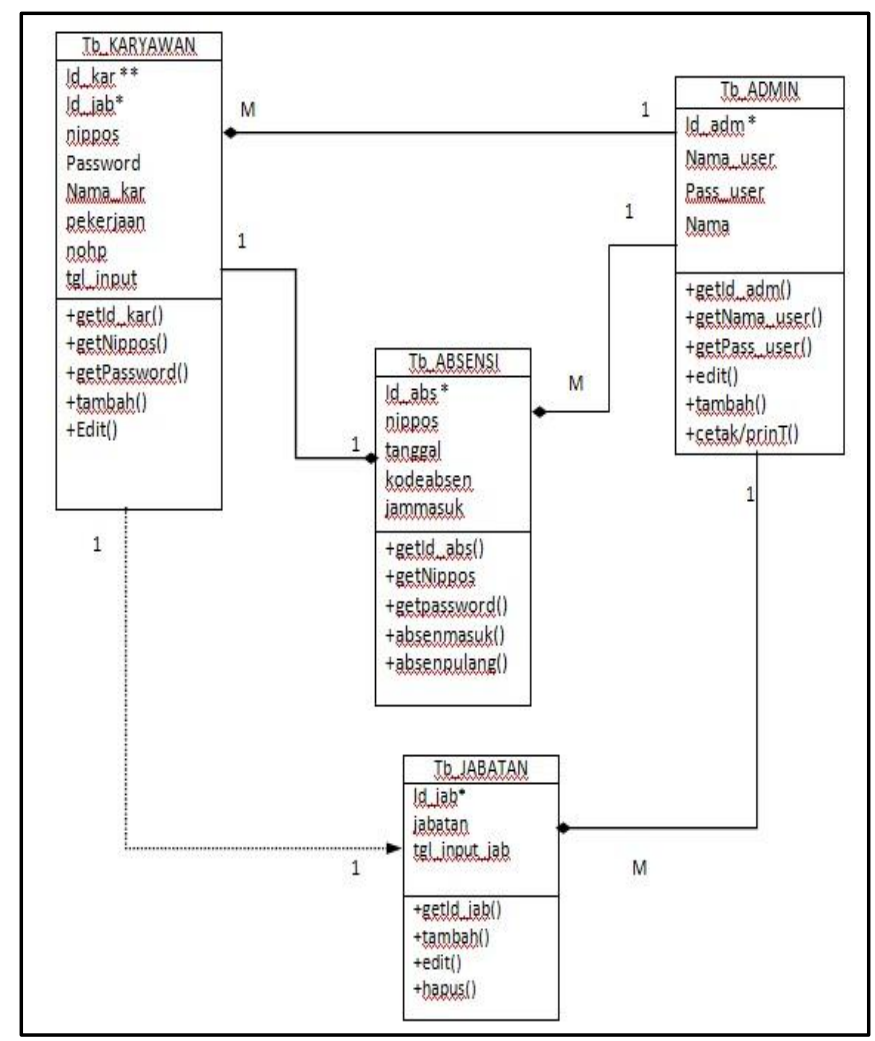

Sumber: Hasil Penelitian (2019)

Gambar 4. LRS Yang Diusulkan

5. Rancangan Halaman

a. Rancangan Halaman Login

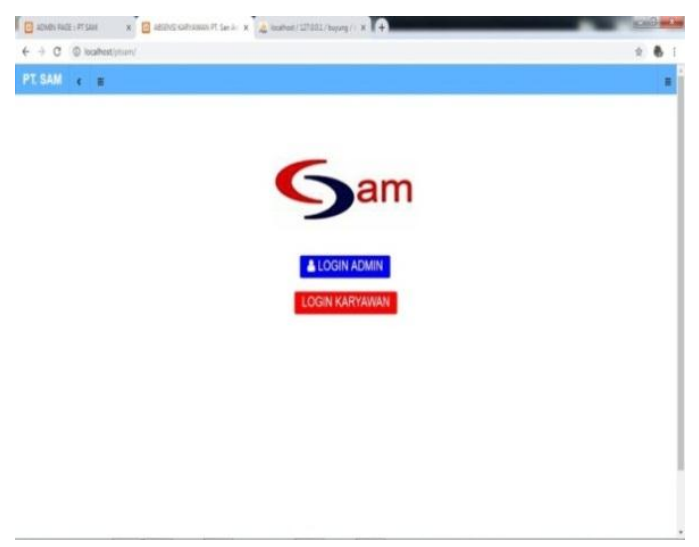

Gambar 5. Rancangan Halaman Login

ejournal.bsi.ac.id/ejurnal/index.php/ijse Copyright @ Universitas Bina Sarana Informatika 
b. Rancangan Halaman Menu Absen Karyawan

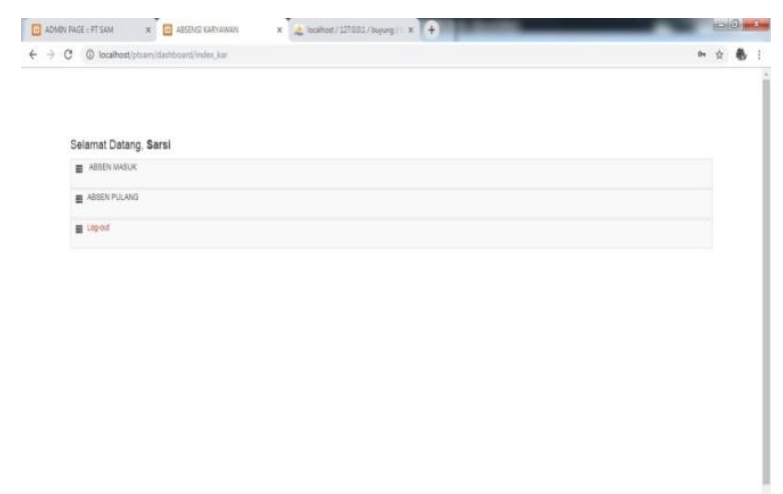

Gambar 6. Rancangan Halaman Absen Karyawan

c. Rancangan Tampilan Menu Admin

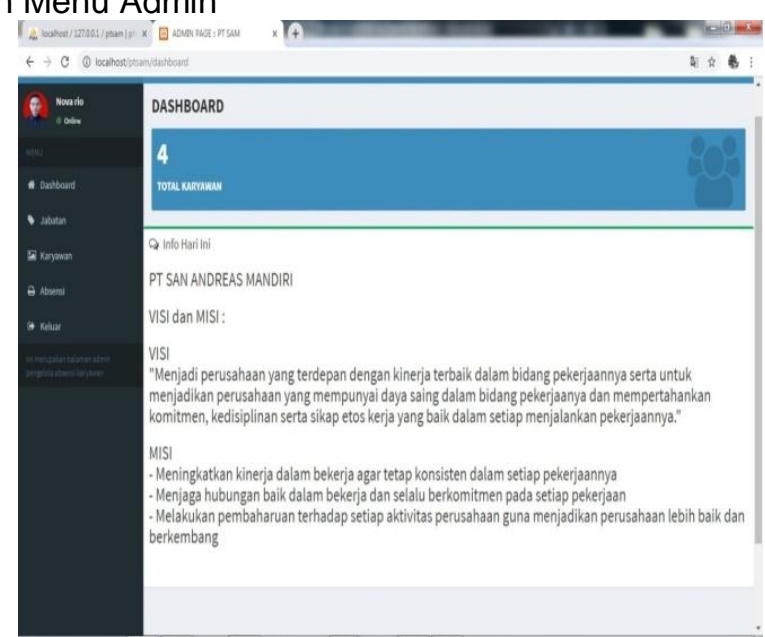

Gambar 7. Rancangan Tampilan Menu Admin

d. Rancangan Menu Cetak Absen

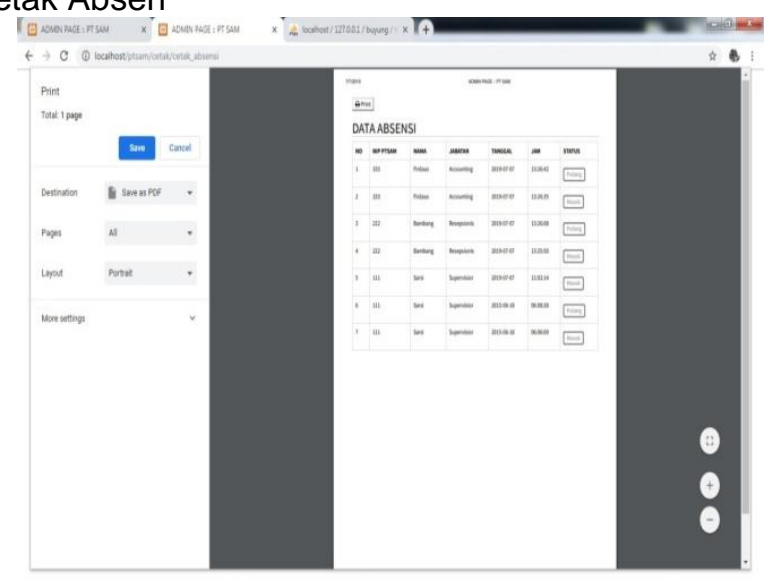

Gambar 8. Rancangan Menu Cetak Absen

ejournal.bsi.ac.id/ejurnal/index.php/ijse

Copyright (c) Universitas Bina Sarana Informatika 


\section{E. KESIMPULAN}

Penelitian ini menghasilkan sebuah sistem informasi absensi karyawan di PT. San Andreas Mandiri yang dapat mencetak laporan kehadiran karyawan dengan mudah dan meminimalisir

kesalahan dalam menentukan sebuah keputusan. Sistem ini sangat mudah digunakan dan cukup efisien dalam penerapannya.

\section{REFERENSI}

Batubara, H. H. (2018). Pembelajaran Berbasis Web dengan Moodle Versi 3.4. Yogyakarta: Deepublish Publisher.

Indrajani. (2015). Data Base Design. Jakarta: Elex Media Komputindo.

Kusrini. (2014). Strategi Perancangan dan Pengelolaan Basis Data. (A. H. Triyuliana, Ed.) Yogyakarta: Andi Offset.

Muslihudin, M., \& Oktafianto. (2016). Analisa dan Perancangan Sistem Informasi Menggunakan Model Terstruktur dan UML. (A. Pramesta, Ed.) Yogyakarta: KDT.

Muslim, B. (2017). Pengantar Teknologi Informasi. Yogyakarta: Deepublish.

Rusmawan, U. (2019). Teknik Penulisan Tugas Akhir dan Skripsi Pemrograman. Jakarta: Elex Media Komputindo. 